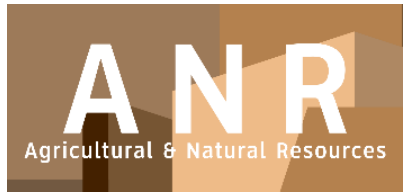

PAPER - OPEN ACCESS

\title{
The Management of Indonesia's Outermost Small Islands as A National Strategic Region Based On Eco Marine Tourism
}

\author{
Author \\ : Arif \\ DOI \\ : 10.32734/anr.v1i2.240 \\ Electronic ISSN \\ : 2654-7023 \\ Print ISSN \\ : 2654-7015 \\ Volume 1 Issue 2 - 2018 TALENTA Conference Series: Agricultural \& Natural Resources (ANR)
}

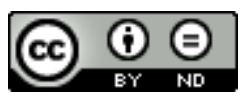

This work is licensed under a Creative Commons Attribution-NoDerivatives 4.0 International License.

Published under licence by TALENTA Publisher, Universitas Sumatera Utara
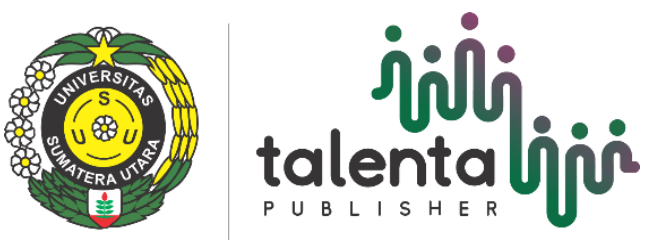


\title{
The Management of Indonesia's Outermost Small Islands as A National Strategic Region Based On Eco Marine Tourism
}

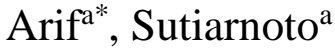 \\ ${ }^{a}$ Universitas Sumatera Utara \\ arif4@usu.ac.id; sutiarnoto@usu.ac.id
}

\begin{abstract}
Indonesia is the largest archipelago country in the world. Referring to UNCLOS, 1982, Indonesia set the outermost small islands as the base line to determine the border of the marine regime with the principle of the island base line. For indonesia the position of the outermost small islands holds a strategic role, especially from the defense aspect, and security to maintain the wholeness of its teritory. This study emphasizes on the law aspect of the mantainance of outermost small islands from several dimensions, such as spatial planning, environment, tourism, institutional, authority management between the central goverment level, province, and the district/town. Facts had shown that in many countries, small islands that are managed effectively and comprehensively to become a tourism destination that gives foreign exchange to a country and gives economical life to its society. In contrary, management of small islands, especially outermost small islands receive quite many challenges, such as; limited accesibility, ports, streets, electricities, telecommunication, and accomodation supports. To show how available legal instruments in management of small islands are implemented, in this study Berhala Island Serdang Bedagai in the Malaka strait which is the base line separating Indonesian and Malaysian territorial waters as a development model of eco marine tourism. Natural resources inventory, and the beauty as tourist attraction, makes Berhala Island Serdang Berdagai promising as a eco marine tourism area. The analysis made towards the law sincronization which regulates the outermost small islands has shown how hard it is to execute development programs of the outermost small islands related to institutional, coordination, management organization changes in the central level aspects, changes in regional authority in managing water regions could be seen as the slowing factor of management momentum in the outermost small islands of Indonesia. Development in nautical tourism in the outermost small islands in Indonesia, at least could shift the approach paradigm from defense and security dimension to local people empowerement dimension, and could also show international society in the effective authorization aspect which in many international juridical decisions is made as judges consideration on ownership territories conflicts of disputed small islands.
\end{abstract}

Keywords : Management; Outermost Small Islands; Regulations; Eco Marine Tourism; Berhala Island Serdang Bedagai;

\section{Introduction}

The purpose of this writing is to show the effort that Indonesia has made as the widest archipelago country in the world in managing the outermost small islands it has. As an archipelago country Indonesia is obliged to report to the general secretary of the United Nations upon the geographic list of coordinate points that connects its outermost islands as a base line of an archipelago country. Because of that it is important for Indonesia to manage its outermost small islands, not only from the management aspect of natural resources, the environment, economy and social, but also related to its defense and security aspect. This writing will start by showing a few consecuences of Indonesia as an archipelago country. Then about how Indonesia manages the outermost islands in the national stage regulation, the local goverment stage, which in the history of local government had been changed as much as three times since 
the reformation era, where every changes has an implication towards the authority of managing the ocean, coast, and small island regions for the local government. Every alteration of government regime also gives an effect towards state ministries structures, also involving the local government managements.

One of the potential environmental services that Berhala Island Serdang Bedagai in the North Sumatera province will be delivered in the end of this writing, to see how an outermost small island could be managed, not only from the strategical importance from the defense and security dimension, but more than that, the outermost small islands that are rich of nature potensials could be used as a marine tourism area based on conservation to show an effective control towards an area that is often used in several international justice forums about the rightful authority of a region by a certain country.

\section{Indonesia's Position As An Archipelago Country}

In international society, Uti Pesidetis Juris principle is applied, a region of a country is a former colony region of another country. This regional aspect, in the international society plays a very important role. Even Oppenheim Lauterpacht emphasized that without a regional legal entities (a country) could not be a country *. Lawyer Huber in the Island of Palmas case stated that regarding this region, sovereignty has two very important characteristics, which is, that sovereignty is a law precondition to a country. The second characteristic is that sovereignty shows that country is independent which also is a function of a country. ${ }^{\dagger}$ Similarly, Indonesia inherits a region which was formerly in the colonial power of Netherlands. This condition makes Indonesia as the biggest archipelago contry in the world. The Ministry of Internal Affairs (2006) said that the sum of Indonesian islands is 17.504.

According to UNCLOS paragraph 121 criteria, what is called an island is: ... a naturally formed area of land, surrounded by water, which is above water at high tide. In 2007 at the United Nations of Expert on Geographical Names (UNEGN) meeting, Indonesia presented a list of 4.918 identificated and named islands. Then in 2011, Indonesia registered 13.487 islands to the United Nations. The naming of islands in Indonesia is based on the President Law Number 112 Year 2006 about the National Team of Name Standarization of Earth Appearance. According to Paragraph 47 verse (9) regulation UNCLOS, 1982, it was stated that: The archipelagic State shall give due publicity to such charts of lists of geographical coordinates and shall deposit a copy of each such chart or list with the Secretary-General of the United Nations. Based on this regulation Indonesia published Goverment Law Number 38 Year 2002 about the List of Geographical Coordinates Base Line Points of Indonesian Islands, which was revised with Goverment Law Number 37 Year 2008 related to the alteration of coordinate base line points because of the separation of Sepadan and Ligitan Islands.

This geographical coordinate points connects the base line of 92 outermost islands of Indonesia. From the 92 outermost islands of Indonesia, there are 12 islands that could potentially cause ownership conflict of other countries, so the Government of Indonesia saw that security is needed upon those 12 islands, and one of the 12 islands is the Berhala Island Serdang Bedagai in North Sumatera province, which is located in Malaka strait separating Indonesian and Malaysian waters.

\footnotetext{
* Oppenheim Lauterpacht, International Law, Vol. I, Edisi 8, Peace Longmans. London, 1967, page 563.

† Huala Adolf, Apek Negara Dalam Hukum Internasional, Raja Grafindo Persada, Jakarta, 1990, page 99.
} 


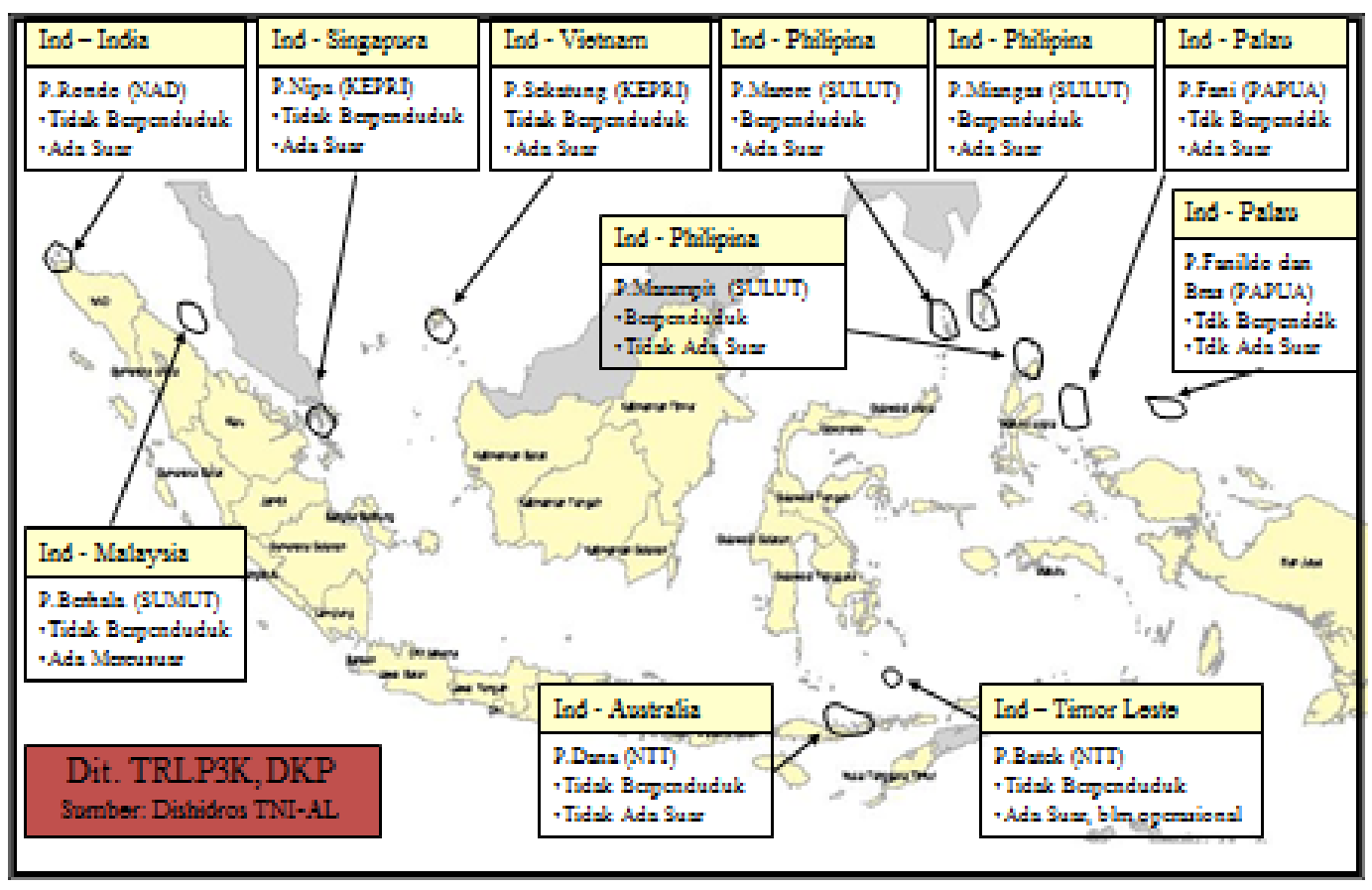

As an archipelago country, Indonesia achieved affirmation upon its sovereignty degree towards waters amongst its islands, which this kind of thinking comes from ICJ verdict in 1951, in Fhisries Case, where the Supreme Court by then gave authority to pull a base line towards few peripheral islands close to the mainland of Norwegia. ${ }^{3}$ $I^{\ddagger}$ ndonesia fought for its status as an archipelago country through a long history, starting from Djuanda Declaration in December 13, 1957 followed by the inception of Peraturan Pemerintah Pengganti Undang-Undang (Perpu) Number 4 Year 1960 about Indonesian Waters.

The Djuanda Declaration is as follows : "In which all surrounding waters, between and which connects islands included in the Republic of Indonesia mainlands, not viewing its width and length is an accepted part of The Republic of Indonesia region and that so is a part of inland waters or national waters that is below the sovereignty of the Republic of Indonesia. The determination of $12 \mathrm{mil}$ sea boundary which is measured from lines that connect the outermost points of the islands of the Republic of Indonesia will be determined by the constitution." The Law Convention of the United Nations in 1982, had accepted the principle of the archipelago country, so it could be said that United Nations Convention about the Seas Law (UNCLOS, 1982) had played a significantly important role towards the economical and social improvement of people in the world, parallel to the cause and principles that is contained in the United Nations Charter, likely for the sustainability of the building of the ocean and seas. ${ }^{\S}$ But it is important to realize that eventhough UNCLOS had created several clues about the status of islands, continental base, closed seas, territorial boundaries, but those clues could not solve claim disputes upon territorial overlaps like in the Southern China Seas territory ${ }^{* *}$. This kind of worries should also push Indonesia to be strict upon determining its territorial boundaries especially in the outermost small island clusters which is made as the base line.

The Indonesian goverment attention towards the outermost small islands is becoming more intensive, at least learning from the experience of the loss of Sepadan and Ligitan island won by Malaysia in the ICJ verdict in 2002. Because of that Indonesia needs to give serious attention towards the outermost islands, eventhough the possibility

$\ddagger$ L. Root, Joshua, The Freedom of Navigation Program : 35 Years Effort, Syracuse Journal of International Law \& Commerce , 2016, page 5 .

$\S$ Nguyen, Dong Manh, Settelement of Disoute Under the 1982 United Nastion Convention of the Law of the Sea, the Case of South China Sea Dispute, University of Queensland Law Journal, (2006), page 146.

** Shen Hongfang, South China Sea Issue in China-ASEAN Relations: An Alternative Approach to Ease the Tension, International Journal of Chine Studies, Vol. 2, No. 3, December 2011, pp. 585-600. 
of ownership conflicts of Indonesia's outermost islands which were contained in geographical coordinate points listed (PP 37 in 2008) is very small, but viewing China's manuver in the waters of Natuna Islands, reminds Indonesia to not be inadvertent in guarding its outermost islands. Especially the potential of mineral, marine and fisheries resources on thousands of outermost and small islands are very large. ${ }^{\dagger \dagger}$ But unfortunately the potential of marine and fisheries on thousands of small islands havent been managed maximally, especially regarding to environmental and conservative services. With wide seas, long coasts,maritime and marine sectors is very strategic to Indonesia seen from economical and environmental, socio-cultural, law and safety aspects. Until now these sectors still lack attention compared to land sectors.

The Reformation Era lead President Gusdur to form the Deparment of Marine and Fisheries for the first time. In the present era of President Joko Widodo, his aim is to make Indonesia the Maritime Shaft of the World. One of the seriousness that is made by President Joko Widodo in his reign is to strengthen the position of maritime or marine, by changing the structure of the Government of Marine and Fishery, which orientates more to the development of maritimes, rather than only focusing towards fisheries issues only.

A historical accident once happened when sistematically foreign nations successfully separated the dimension synergy of agrarian and maritime, manipulating and planting a certain way of thinking that Indonesian nations should state that its identity is an agrarian nation and forget its identity as a maritime nation. ${ }^{\S \S}$ It could be said that since Indonesia's independency, it has never managed the competency of the Local Government in sea spaces, coasts, and small islands. The competency of the Local Government in the sea spaces, coasts, and small islands emerged with the Constitution Number 22 in 1999 about the Local Government, by that assertion of authority caused horizontal conflict between fishermen, to this day. The paradigm shift of local government management is constantly changing, and alongside of the changes the local government's ability to adapt to respond to the changes is very slow including the management towards the outermost small islands. In the President SBY era various regulations were issued related to the management of the coast area and small islands, before constitutional laws are inforced that could arrange better and more comprehensively regarding the outermost small islands.

\section{The Regulation Regarding The Outermost Small Islands}

According to the facts, that the outermost small islands contain potential maritime natural resources, an outstanding environmental service, where the opportunity to develop it into a business field is really huge. ${ }^{* *}$ But at the other side the management of the outermost small islands needs very large resources, especially regarding the posititon of the outermost small islands located at the front line in the border area. From 92 outermost small islands that had became the border line of the Indonesian waters, there are 31 populated islands. The President Law (Peraturan Pemerintah; PerPres) Number 78 in 2005 regarding the Management of the Outermost Small Islands is a regulation that was born as an anticipative step before the Constitutional Law about The Management of the Coast and Small Islands Number 27 in 2007 was born. According to PerPres Number 78 in 2005 it is said in Paragraph 2 that the purpose of management of outermost small islands are : (a) to preserve the integrity of Negara Kesatuan Republik Indonesia (NKRI) region, the national security, the country and nation defense, and also create regional stability, (b) using natural resources for continuous building, and (c) to empower society to increase welfare. PerPres Number 78 in 2005 is an anticipative step before Indonesia had a guideline to manage the outermost small islands. Noting the purpose of managing the outermost small islands according to this PerPres, it is clearly stated that one of them is associated with maintaining the regional stability. By then the management of the outermost

\footnotetext{
${ }^{\dagger}$ Idris, Irwandi, Ginting, Sapta Putra, Budiman, Membangunkan Raksasa Ekonimi (Sebuah Kajian terhadap Perundang-undangan Pengelolaan Wilayah Pesisir dan Pulau-pulau Kecil, (Penerbit Buku Ilmiah Populer, Bogor : 2007), page 47.

¥ Forum Rektor Indonesia- Universitas Sumatera Utara, Naskah Akademik Menegakkan Negara Maritim Bermartabat, ( CV. Ratu Jaya : 2015), page 1 .

${ }_{\S \S}^{\S}$ Prosiding Seminar Pengawasan dan Pengendalian Pengelolaan Pulau-pulau Kecil, Direktorat Jenderal Pengawasan dan Pengendalian Sumberdaya Kelautan dan Perikanan, Depaartemen Kelautan dan Perikanan,(Jakarta : 2006), page 5.

${ }^{* * *}$ Prosiding Sarasehan Sumberdaya Tata Ruang Nasional Yang Berjatidiri, Pusat Studi Sumberdaya Lahan, Universitas Gadjahmada, (Yogyakarta) : 2009, page 3.
} 
small islands prevents conflict to happen with other countries, moreover the countries that is immediately adjacent to numerous outermost small islands of Indonesia. From the defense and safety aspect, this outermost small islands need not only to be guarded from possible claims from other countries, but the small islands need to be guarded from possible uses of crime such as smuggling, pirates, narcotics, human trafficing and other forms of crime.

Another purpose of the management of the outermost small islands to empower the natural resources to sustainable development. This purpose could be done by making the outermost small islands rich of enviromental services potential as a marine tourism region. Fully sovereign rights towards the outermost small islands could be used to encourage the development of sea based future. ${ }^{\dagger \dagger \dagger}$

Since Indonesia has given fairly high attention towards the huge maritime potential, alongside grew also laws that is given to empower the small islands and the outermost small islands, A few laws related to small islands are as follows :

\section{a. Constitution Law Number 27 in 2007 about The Management of Coast and Small Islands.}

One of the considerations of Constitution Law Number 27 in 2007 about the Management of Coast and Small Islands is that the coast and small islands have several high potential natural resources, and it is very important for the development of social, economy, cultural, environmental, and the buffering of sovereignty of a nation, hence it needs to be managed continuously and be global insighted, by being concern towards the people's aspiration and participation, and the nation value according to the national law norm.

The purpose of the management of the coast region and small islands according to this constitution law is : (a) to protect, conserve, rehabilitate, use, and enrich the coast and small islands resources and also their ecological system continuously, (b) to create a harmony and synergy between the government and the local government in managing the coast and small islands resources, (c) strengthining the role of the people and government institutions and also pushing the people's initiative in managing the coast and small island resources to achive equality, balance, and sustainability, (d) enhancing the social, economic, and society cultural values through society participation in the usage of coast and small islands resources.

The Constitution Law Number 27 in 2007 contained a breakthrough that is given as an effort to accelerate the society well-being living in the coast and small islands, by regulating the governance of Rights of Cultivating Water Coast (Hak Pengusahaan Perairan Pesisir) or usually known as HP-3. HP-3 in general is an assurance given by the country to the society towards the rights to manage the water column in the coast and small islands that is identic to cultivation of soil on the mainland. With rights like this the society are given the right to cultivate water columns just as cultivating a piece of land, and so by that rights in the coast that is reigned by the society could be given rights to be altered and also other rights.

This condition made strong reactions from various elements of the society, especially the activists and observers of traditional fishermen's lives and cultural society rights, that regards the giving of HP-3 will give opportunities for private parties and capital owners to exploit the coast and small islands regions. In contrary the cultural society, locals and fishermen, especially traditional fishermen will not have access towards HP-3 because they do not have the ability to master HP-3. This problem is then brought by people who are against HP-3 to the realm of law by proposing Judicial Review to the Constitutional Court. By the Constitutional Court the demand of HP-3 elimination is granted in the Constitutional Court decision Number 3/PUU-VIII/2010.

One of the base of consideration by the Constitutional Court lawyer is the presence of HP-3 will issue private practice in the water and coast, and will make the economical status in that region not to be prepared as joint ventures based on familial principles as contained in Chapter 33 verse (1) UUD 1945. This could potentialy cause carved up waters and cause loss of responsibiblity of the nation towards coast society, the loss of the sea as a common access, the loss of colectivity of economic waters and coast that is manufactured and used by cultural, traditional, and local societies. Referring to the Constitutional Court Desicion Number 001, 021, 022/PUU-I/2003 on 15 December 2004 that states that if the meaning of "overpowered by the country" only meant as an private ownership by the country, then it is insufficient to achieve the purpose of "for the people's welfare".

\footnotetext{
††' Kementerian Kelauatan Perikanan Republik Indonesia, Membangun Negeri Kepulauan, (Jakarta) : 2014.Page 6.

林http://endyonisius.blogspot.co.id/2011/08/tinjauan-keputusan-mahkamah-konstitusi.html, diakses tanggal 7 Oktober 2016.
} 


\section{b. Constitution Law Number 32 in 2014 about The Marine}

One of the Constitution law that also manages small islands is constitution law nuber 32 in 2014. This law is made for an effort to create a comprehensive regulation regarding the management of the marine. In the Constitution Law Number 32 in 2014 it is said that the marine is anything related to the sea and/or activities in the sea region that covers the seabed and the land below it, water columns and water surfaces, including the coast and small islands. Besides that the constitution law number 32 in 2014 also regulates upon the economical policy which also makes the marine as a basis of the economic building. The basis of the marine economic building is prioritized to the coast society. Constitution law number 32 in 2014 stated that the management and usage of coast and small island resources are done with planning, usage, surveillance, and controlling activities.

\section{c. Constitution Law Number 23 in 2014 about Local Government}

Constitution Law Number 23 in 2014 about Local Government is the law that replaces Constitution Law Number 32 in 2004 about the Local Government. In Constitution Law Number 23 in 2014 contains arrangement about the division of government affairs between the Central Government and the Local Government (Province and District/City). One of the division affairs relates to the affair of marine and fishery. In Chapter 9 of Constitution Law Number 23 in 2014 divides the government affairs into three, which are absolute government affairs, concurrent government affairs, and general government affairs. Absolute government affairs are governmental affairs that is fully becoming the authority of the Central Government, such as : foreign policy, deffense, security, judicial, moneter and fiscal, and religion.

Concurrent government affairs are government affairs that are divided between the Central Government and the Province and the District/City region. The marine and fishery which the small islands become the integral part is the affair of selected government, but in the management it is only divided between the Central Government and the Province regeion. In other words, the District/City Government does not have the authority towards the management of seas, coasts, and small islands regions.

In this study is found that the diversion of authority in the maintainance of the marine, coasts, and small islands, causes problems in the field, such as :

1) Constitution Law Number 27 in 2007 about the Management of Coast and Small islands instructs District/City Government to set the plan of zoning coasts and small islands regions in the Local Regulation. In this context, until the Constitution Law Number 23 in 2014 about Local Government has been enacted, not all District/City Government in North Sumatera has constructed the Planning of Zoning the Coast and Small Island Regions. To areas where the constitution law about the local government is enacted is still constructing the planning of zoning the coast and small island regions, do not continue the process of constructing this zoning planning because they have no more authority towards the sea, coast, and small islands, except towards the development of traditional fishermen.

2) In general the District/City government when still enacting the previous constitution law of local government, does its authority towards coast and small island regions, but with the regulation of Constitution Law Number 23 in 2014, they stopped the activities and programs of managing the small islands. In this study the Government of Serdang Bedagai District who has been managing the Berhala Island which became the region of this study has sopped activities and programs in Berhala Island. Serdang Bedagai District had had the Local Regulation Number 12 in 2006 about the Management of Berhala Island as a Eco Marine Tourism Region. Now the Government of Serdang Bedagai District has stopped all activities relating to Berhala Island Serdang Bedagai.

3) In the other side there is no clarity of how the handover and transition of the authority in the government in the field of marine, coast and small islands had been done that makes these authorities also not done by the province government. In the context of Berhala Island that is the object of this study, the Province Government of North Sumatera has not done many things in relation to the presence of Berhala Island. 
4) The other aspects that could not be found in this study is related to the changing of the Central Government (The president and its Cabinets) gives an impact towards the region's ability to adapt towards the structural change of the Marine and Fishery Government in the Central stage. Before the Law of Marine and Fishery Government of Indonesia Number 23/PERMEN-KP/2015 about Organization and the Working Procedure of Marine and Fishery Government, the management of coast and small island regions was in one Directorate General, which is the Marine, Coast and Small Islands DG, as is regulated in the Law of Marine and Fishery Minister Number : PER.15/MEN/2010 about the Organization and the Working Procedure of the Marine and Fishery Minister. Now the management of small islands is below the Directorate General of Management of Marine Space, that consists of Marine Spatial Planning Directorate, Utilization of Coastal Directorate, Utilization of Small Islands Directorate, Marine Directorate and Conservation and Marine Biodiversity Directorate. Based upon the interview with Ibu Erna dewi The Head of Management of Coast and Small Islands Agency of Fishery and Marine of North Sumatera Province, until now the Agency of Fishery and Marine are still using the old nomenclature. It means that there has not been any adaptation towards the organization in the central stage.

\section{The Presence Of Berhala Island As An Eco Marine Tourism Region}

The development of Berhala Island Serdang Bedagai as an eco marine tourism region has a good prospect seen from the point of view of the society involvement in the management.The district of Serdang Bedagai as the district that has the authority in managing the Berhala Island had launched Perda Number 12 in 2006 about Management of Berhala Island as an Eco Marine Tourism. By determining Berhala Island as an Eco Marine Tourism, it is only left on how the plan is executed. Berhala Island is actually a region consisting of three islands, each island with its own uniqueness.

Berhala Island (Main) has a montane topography with dense forests and white clean beaches. The topography consists of hills and stony corners that projects to the sea, with only one side of the island with a sloping beach. The coastline of the Berhala island $\pm 700 \mathrm{~m}$ with most of the beaches are clusters of large stones. Beach sands between Berhala Island and Sokong Nenek Island is the place of Turtle Hatching. Coral reefs located arround Berhala Island are generally young coral reefs that need to be preserved.

In the Berhala Island there is a Primary Forest which has very old aged trees. Big trees such as Rengat, Jeluntung, and Meranti decorates the island with the area of $\pm 40,351 \mathrm{Ha}$. In the forest, lives various animals such as Napu (a kind of Mouse Deer), Biawak, Turtle, Snakes, and various other creatures. This forest is the buffer of availability of fresh water in this area. The water sourcing from the roots of the trees and rocks are very clean and clear with a very good quality of water. Many fishermen who sails around Malaka Strait always comes to this Island to take freshwater supplies.

Besides the charm of the forest and rock panorama, Berhala Island is also surrounded by a coral reef belt. Various kinds of coral reefs are located in the Berhala Island region.

In the Berhala Island region, various fishes still could be found near the rocky waters. In the coral reefs, mostly reef fishes are found such as kakatua, kwe, kerapu, and tenggiri. The coral beach and the blue-greenish water surrounding the Berhala is rich upon sea biota. Not only fishes, but also clams, snails, squids, even salted water crabs could easily be found arround Berhala waters. In the depth of 9 metres, the base of the sea could still be seen clearly. Behind that clearness, one colorful garden awaits. Algae, seaweed, and also colorful coral reefs that are still whole. Between them, fishes with various sizes cluster, shimmies and makes specific movements, these various sized and colored fishes are not easily distrubed by the presence of human beings. This is also supported by the sea biota collection that is also unique and rare such as ketam kelapa, kima raksasa, and ikan bulu ayam. Diving activities that could reach 9 metres could be done using diving utensils.

From the infrastructure readiness, the presence of Berhala Island Serdang Bedagai has to get a special attention from the Central Government, North Sumatera Province Government, and the people of Tanjung Beringin district, the access to Berhala Island is usually from the dock of TPI in Bagan Kuala Village, District Tanjung Berinign. Untul now there is still no safe and comfortable transportation that could be used by tourists heading to Berhala 
Island. With a relatively expensive tourism package, Berhala Island Serdang Bedagai is being sold by a few travel agents using Boat Cepat transportation that is managed by the manager of Siba Island in Belawan. From Belawan using a fast boat, Berhala Island could be reached by 2 hours journey from Belawan dock.

Other alternatives that could be used by tourists heading to Berhala Island is through the roadway from Medan to Tanjung Beringin with 2-3 hours journey from Medan. Then from TPI Tanjung Beringin Dock the visitors could head to the island using a boat or a fishermen boat with various sizes, with a 3-4 hours journey. Because the fishermen boats are not prepared for tourism purposes, the image is far from safe and comfortable. Even so, to minimize the risk of fatal accidents in the sea, by the people who gives services of visits to Berhala Island, life jackets are provided to all passengers that are sailing towards Berhala Island with one life jacket rental of Rp. $10.000,-$

Other procedures that all visitors of Berhala Island have to do is telling the Sea Security station in Tanjung Beringin to be continued to the TNI-AL Safety Station that is stationed in Berhala Island. With the position of a National Strategic Region from Defense and Safety aspect, the Berhala Island is still guarded by TNI-AI and TNI$\mathrm{AD}$ intermittently.

A few activities could be done by visitors in Berhala Island such as : snorkling, diving, fishing, fun games with water and other activities. A few facilities in Berhala Islands are : Stiger (boat landing) that is built by the District Government of Serdang Bedagai, Jalan Lingkungan which connects until the ladder to arrive at a lighthouse managed by the Navigation Director General of Sea, Minister of Communication RI. In the present in Berhala Island some buildings has been built that could be used for resting places for visitors. As for consumtion, usually the visitors have prepared before departure.

According to the observation from this study a lot of things need to be fixed if Berhala Island as a National Strategic Region is to be used as a tourist destination in North Sumatera. In the planning of Indu Pembangunan Kepariwisataan in the Province of North Sumatera, Berhala Island region is included in the tourism destination area (Destinasi Pariwisata Daerah - DPD) in the eastern coast of North Sumatera that consists of a few Strategic Regions of Local Tourism (Kawasan Strategis Pariwisata Daerah - KSPD) such as :

a) KSPD Kampai Island and its surroundings;

b) KSPD Tanjung Pura and its surroundings;

c) KSPD Karang Gading, Langkat Timur Laut;

d) KSPD Belawan;

e) KSPD Percut;

f) KSPD Pantai Cermin;

g) KSPD Pantai Labu;

h) KSPD Nagalawan;

i) KSPD Berhala Sedang Bedagai Island;

j) KSPD Pandang Island and Salah Nama Island;

All KSPD mentioned above is a destination that has prospect to be developed as a tourist destination in the local scale as well as national scale. From the tourism building aspect is needed approaches related to : tourism destination, tourism industry, tourism marketing, and tourism institution. In the relation towards the development of Berhala Island as a National Strategic Region as well as a tourism destination as an eco marine tourism, it needs a lot of stakeholder involvements, starting from the Central Government, Local Government, tourism businesses, local society, universities, and also other parties including TNI as a guard of the outermost islands.

\section{Conclusion}

Berhala Island's status as a national strategic region in North Sumatera from the upholding sovereignty of NKRI needs special attention, as Berhala Island Serdang Bedagai is one of the 12 outermost Islands of Indonesia that is endangered of claims, and as a result of high sailing activities in Malaka Strait. In this unpopulated island if not guarded specially could be used by groups of national or foreigners to do crime, such as piracy, smuggling, and so 
on. The appoinment of Berhala Serdang Bedagai as KSN is very appropriate and by that effective steps need to be done to show international society the effectiness occupation as a real proof of Berhala Serdang Bedagai belonging to Indonesia. Placement of Security Forces of the Outermost Islands TNI-AL who are in Berhala Serdang Begadai Island is still needed to maintain the sovereignty of NKRI.

The chances of management of Berhala Island Serdang Bedagai as a national strategic region from the defense and security aspect, in the other side could be used as a eco marine tourism region by TNI-AL could be accepted and in the TNI-AL doctrine the more society involved in securing a region, the better it is. Putting Berhala Island Serdang Bedagai as Eco Marine Tourism is also correct, because of how much nature appeal and nautical tourism charm provided in the island.

Conservation steps that has to be done to support the ecosistem environment of Berhala Island Serdang Bedagai has been done by the District Government of Serdang Bedagai Island by Peraturan Daerah Kabupaten Serdang Bedagai Number 12 in 2006 about management of Berhala Serdang Bedagai as a Eco Marine Tourism region that is supported by various laws as written in National Region Spatial Planning, Province Region Spatial Planning, and District Region Spatial Planning.

The conservation area in Berhala Island Serdang Bedagai needs to be supported by forming Kawasan Konservasi Laut daerah (KKLD) which is organized in The North Sumatera Province Local Law Number 5 in 2008 about Management of Coast and Small Islands. The Primary forest in Berhala Island with various flora and fauna needs to be maintained. The unique animal in Berhala Island that needs to be conserved is Penyu Belimbung that has its captivity in Berhala Island.

Berhala Island Serdang Bedagai in the development of regional tourism in North Sumatera has been appointed as Strategic Regions of Local Tourism (Kawasan Strategis Pariwisata Daerah - KSPD) in tourism destination area (Destinasi Pariwisata Daerah - DPD) in the East Region of North Sumatera that started from Pulang Kampai and surroundings in the district of Langkat until Sikantan Island in the district of Labuhanbatu. Berhala Serdang Bedagai as KSPD in the Rencana Induk Pembangunan Kepariwisataan Daerah (RIPPARDA) in the North Sumatera Province could be the base of development in the coast and small islands which the authority has been given to the Province Government in the Constitutional Law Number 23 of 2014 about Local Government.

\section{References}

[1] Adolf, Huala, Apek Negara Dalam Hukum Internasional, Raja Grafindo Persada, Jakarta, 1990.

[2] Dong Manh, Nguyen, , Settelement of Disoute Under the 1982 United Nastion Convention of the Law of the Sea, the Case of South China Sea Dispute, University of Queensland Law Journal, (2006)Oppenheim Lauterpacht, International Law, Vol. I, Edisi 8, Peace Longmans. London, 1967.

[3] Forum Rektor Indonesia- Universitas Sumatera Utara, Naskah Akademik Menegakkan Negara Maritim Bermartabat, ( CV. Ratu Jaya : 2015).

[4] Hongfang, Shen, South China Sea Issue in China-ASEAN Relations: An Alternative Approach to Ease the Tension, International Journal of Chine Studies, Vol. 2, No. 3, December 2011

[5] Idris, Irwandi, Ginting, Sapta Putra, Budiman, Membangunkan Raksasa Ekonimi (Sebuah Kajian terhadap Perundang-undangan Pengelolaan Wilayah Pesisir dan Pulau-pulau Kecil, (Penerbit Buku Ilmiah Populer, Bogor : 2007)

[6] Joshua, L. Root, , The Freedom of Navigation Program : 35 Years Effort, Syracuse Journal of International Law \& Commerce, 2016.

[7] Kementerian Kelauatan Perikanan Republik Indonesia, Membangun Negeri Kepulauan, (Jakarta) : 2014

[8] Prosiding Seminar Pengawasan dan Pengendalian Pengelolaan Pulau-pulau Kecil, Direktorat Jenderal Pengawasan dan Pengendalian Sumberdaya Kelautan dan Perikanan, Depaartemen Kelautan dan Perikanan,(Jakarta : 2006)

[9] Prosiding Sarasehan Sumberdaya Tata Ruang Nasional Yang Berjatidiri, Pusat Studi Sumberdaya Lahan, Universitas Gadjahmada, (Yogyakarta) : 2009

[10] http://endyonisius.blogspot.co.id/2011/08/tinjauan-keputusan-mahkamah-konstitusi.html, 